\title{
Of, By, and for Which People? Government and Contested Heritage in the American Midwest
}

\author{
Elizabeth Kryder-Reid and Larry J. Zimmerman
}

\section{INTRODUCTION}

"Government of the people, by the people, for the people, shall not perish from the Earth." When President Abraham Lincoln spoke these final words of his address at Gettysburg in November 1863, the audience was reportedly unimpressed by the two-minute speech. But over the years this phrase has come to symbolize the ideals of American democracy. The USA is, in Lincoln's words, a nation "conceived in liberty, and dedicated to the proposition that all men are created equal." Heritage practices, however, often complicate such high ideals in the face of competing interests and political power. Democracies require both representative and participatory governance, but which voices are represented and who participates? State-sponsored heritage sites, particularly those involving contested heritage, expose the fissures and frictions of

E. Kryder-Reid $(\varangle)$. L. J. Zimmerman

Indiana University School of Liberal Arts at IUPUI, Indianapolis, IN, USA

(C) The Author(s) 2018

J. Rodenberg and P. Wagenaar (eds.), Cultural Contestation,

Palgrave Studies in Cultural Heritage and Conflict, https://doi.org/10.1007/978-3-319-91914-0_12 
government roles in managing and interpreting the past, and they may also demonstrate the strategies of resistance that influence governmental decisions.

Examined in this study are two contested heritage sites located in central Indiana, just north of Indianapolis, Indiana, in the heart of the American Midwest. ${ }^{1}$ Mounds State Park (Mounds), ${ }^{2}$ as the name implies, is one of the twenty-five parks owned and operated by the state of Indiana, while Strawtown Koteewi is one of the eleven public parks operated by the Hamilton County Parks and Recreation Department. ${ }^{3}$ Mounds was established in 1930 and is listed on the National Register of Historic Places because of its earthworks dating to the late Archaic culture known as the Adena-Hopewell. Archaeologists hypothesize that Native Americans constructed the largest earthwork, the Great Mound, around 160 BC (Squire and Davis 1848; Cochran and McCord 2001). The mounds were primarily used as gathering places for religious ceremonies and probably constructed to align with astronomical events. While the 250-acre park contains a nature preserve and a unique fen environment, a campground, Nature Center, and miles of trails, it was dedicated, as the Interpretive Master Plan notes, "for the purpose of protecting a nationally recognized cultural site" (Mounds State Park 2011).

Strawtown Koteewi is a much newer park, created in 1999 when the county purchased 750 acres from the estate of a local resident. The relatively undeveloped land was known to contain numerous significant archaeological sites, as well as woods, prairies, and 3.25 miles of wetlands along the White River that surrounds three sides of the park. Like Mounds, the park was developed for recreational uses and now contains not only hiking and horseback riding trails, but also an archery range, high ropes course, and zip lines. Strawtown's Native American history is also more recent; while it was likely occupied much earlier, its most significant sites are an enclosed village site dating between $1250 \mathrm{AD}$ and $1400 \mathrm{AD}$, a period known as the Oliver Phase of the Middle Woodland tradition. ${ }^{4}$ Strawtown Koteewi has been the focus of intense archaeological investigation and had an active volunteer archaeology program for a decade (McCullough 2011). ${ }^{5}$ In addition to the excavations, the Park runs public programs and maintains a permanent exhibit in the Taylor Nature Center. Both sites are valued as publicly accessible places to connect with nature, as sources of archaeological knowledge, and as places to learn about the past. 


\section{Contested Heritage}

The parks used today for education and recreation are the homelands of Native Americans who were dispossessed through a series of violent encounters and negotiated treaties as part of the American colonial project, then removed to Indian Territory in what is now the state of Oklahoma. Multiple tribes have cultural affiliations to Indiana including the Miami, Delaware, Shawnee, Wea, and the Potawatomie. In addition, the Pokagon Potawatomi, though technically in Michigan, have large populations in the six Indiana border counties. The official recognition of these tribes is complicated, due to the history of Indian removal by the US government in the nineteenth century, and several of the affiliated groups with federal recognition are based in other states (the Miami of Oklahoma, three federally recognized bands of Shawnee in Oklahoma, the Delaware of Oklahoma, and the Pokagon Potawatomi in Michigan have federal tribal recognition). ${ }^{6}$ To further complicate the issue of recognition is that descendants of remnant populations that stayed in Indiana in the 1800s have sought state and federal recognition. One consequence of this history is that the claims to the sites by Native peoples are entangled in broader issues of control, legitimacy, access to resources, and both inter- and intra-tribal relationships.

A second aspect of the contested heritage is that while the sites are valued by some as important sources of knowledge about the deep past, they are also seen by others as sacred sites (Kryder-Reid et al. 2017). The circular mounds at Mound State Park have astronomical alignments to the equinoxes and solstices and are important evidence for understanding the cosmologies of the Adena-Hopewell cultures. Strawtown Koteewi has only recently been available for archaeological investigation and is a significant settlement site from what archaeologists label the Oliver Phase of the Middle Woodland tradition. The sites have also been popular for volunteers, particularly during "Archaeology Week" which is organized each September. The archaeological research was conducted with the knowledge and cooperation of some tribal representatives, but given the complex history of association with the area and changes in elected leadership of tribal governments, others have objected to the excavations. At particular issue is the perception of disturbance of human remains and the belief that the site itself is hallowed ground because of the presence of those remains regardless of the context of intact burials. One outcome is that the Miami of Oklahoma have filed repatriation 
claims that have resulted in the return of a significant number of artifacts, both those mandated by NAGPRA and additional items falling outside of NAGPRA criteria, but being returned in the spirit of the law. Another outcome is that the NAGPRA claims have generated several stories in local, tribal, and national news media highly critical of park management of archaeological resources (Sikich 2017). ${ }^{7}$ Furthermore, even with the resolution of the NAPGRA claims, there remains a conflict among those who use both parks as recreational sites, those who value their potential for scientific and archaeological research, and those who see them as sacred sites of their ancestors.

A third context for understanding the contested heritage of these sites is the tension between preservation and economic development. At Strawtown, the development of the ropes course and archery range, which produce income, has been challenged for the impact on the natural resources such as birds' nesting areas. At Mounds, the debate has centered on where a group looking hopes to stimulate the depressed economy of the region by creating a reservoir. The proposed Mounds Lake project would build an earthen dam on the West Fork White River, backing up water for approximately seven miles into Delaware County and creating a reservoir projected to be 30-50 feet deep, 7 miles in length, with an overall surface area of approximately 2000 acres or more than 800 hectares. The idea was first generated at a Madison County Leadership Academy visioning session in 2010 followed by a privately funded Phase 1 feasibility study that framed the primary purpose of the reservoir as an economic development catalyst. When the state-funded Phase 2 study was being conducted, the developers learned that public waterways cannot be dammed for economic development reasons, and they shifted the purpose of the reservoir to ensuring an adequate and safe water supply for the future, even though no water companies had indicated the need. The proposed dam project would inundate about a third of the Mounds State Park property, and while the mounds themselves would not be flooded, the cultural landscape would be profoundly altered, and the earthworks may become more vulnerable to erosion. The proposed project generated heated public debate about the merits of the proposed project. Some people saw it as a bold but necessary gamble to provide jobs and stimulate the economy in an area hard hit first by the bust of natural gas production and then by the closing of a major manufacturing plant. Others opposed it for its damage to sensitive habitats and rare species, its flooding of low-income neighborhoods, and its impact on valued recreational and cultural resources (Kryder-Reid 2015). 


\section{The Role of Government in Contested Heritage}

Government is inextricable from cultural contestations about cultural heritage resulting from legislation, policy, and funding, as well as having direct control of, and authority over, heritage resources (Laurence 2010). This case study of Strawtown Koteewi and Mounds State Park exposes the fissures between authorized heritage discourse and the paradigms of meaning among the diverse constituencies of the sites, and it highlights the tenuous position of public governance in privileging competing cultural, economic, and social interests. The study also exemplifies the constraints and motivations of the state apparatus of heritage management.

At Strawtown, the NAGPRA claims filed by the Miami of Oklahoma led to a halt in any active excavations. At the same time, in response to a survey conducted by the Hamilton County Tourism office, the Hamilton County of Parks and Recreation constructed a massive, 50 by 50 -foot-simulated excavation in poured concrete, complete with inset artifacts and features, and with soil layers indicated by different tints and dated artifacts (Fig. 12.1).

The outdoor exhibit is intended to give visitors the chance to "look through the lens of an archaeologist as they discover historic and pre-contact artifacts. House basins, hearths, and trash pits are only a few of the traces that remain" (Hamilton County 2016). The Parks Department also began constructing what is described as "full-scale, American Indian structures" representing "an American Indian village that was inhabited more than 700 years ago (Fig. 12.2)."

At Mounds, there is a similar disconnect in that when faced with deeply divisive contestation about the Mounds Reservoir project, the position of the Indiana Department of Natural Resources, which owns and runs the park, was officially "neutral." Furthermore, despite a plethora of statements from not-for-profit entities ranging from the Indiana Archaeology Council to the Indiana Forest Alliance, no government agency or entity has publicly spoken against the project (Kryder-Reid 2015).

So, what is to be learned from a county park that builds a mock dig and reconstructs an Indian village while ceasing archaeological excavations and remaining at an impasse after three years of negotiations with tribal communities? What is the significance of a state agency that has remained silent in the face of plans to flood one of the most significant cultural heritage sites in the parks system? What do these two case studies reveal about the role of government in cultural heritage management? 


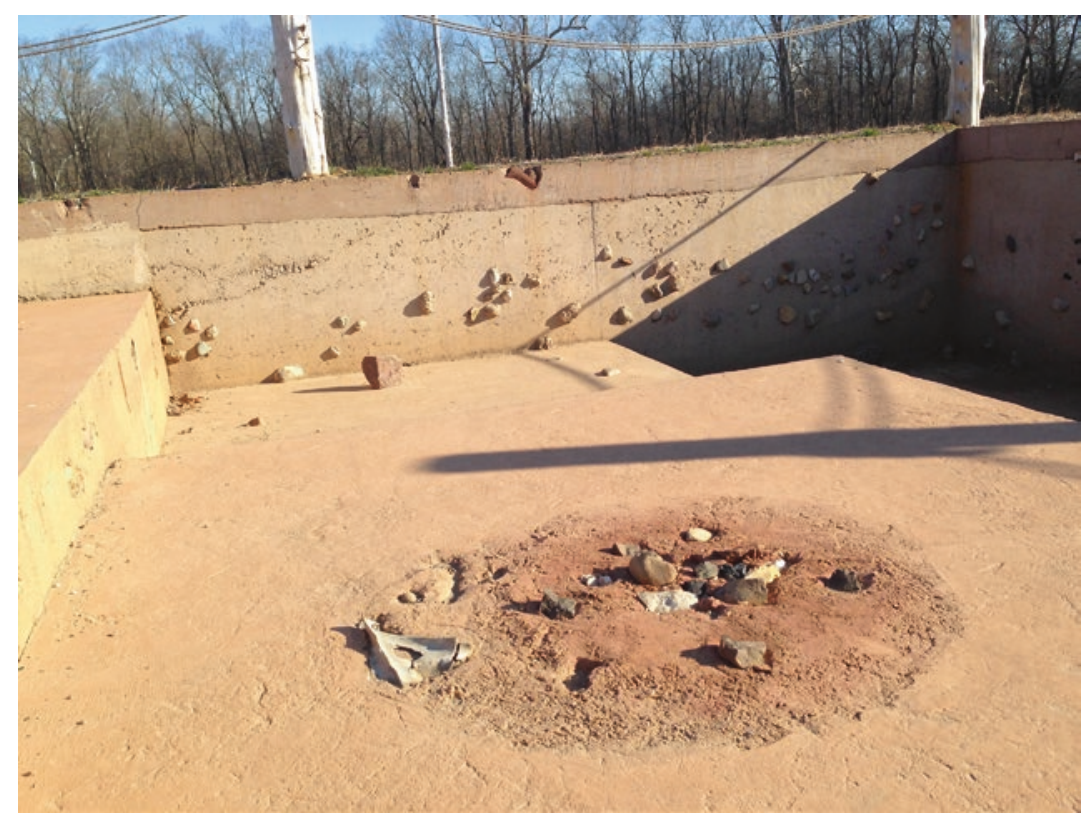

Fig. 12.1 Simulated 50 by 50 -foot-poured concrete excavation at Strawtown Koteewi, Hamilton Co., Indiana (Photo: Elizabeth Kryder-Reid)

These cases raise several points that are important for broader investigation of government and heritage. The first is that the notion of "public heritage" needs to be disrupted. Save for rare exceptions, a heritage about which people are the most passionate is usually local, associated with places mostly meaningful to them as members of a relatively small group with well-defined ethnic boundaries and shared historical experience. Information about such heritage and the meaning and emotional responses it generates are often completely inaccessible to outsiders. Heritage is primarily experienced, understood, defined, and shared locally, but when archaeologists or other heritage specialists define heritage without collaboration with local groups it can be seen as colonizing as Smith and Waterton (2009), Zimmerman (2010), Harrison (2012), and others have argued. Furthermore, while heritage professionals and organizations have begun to implement the concepts of shared 


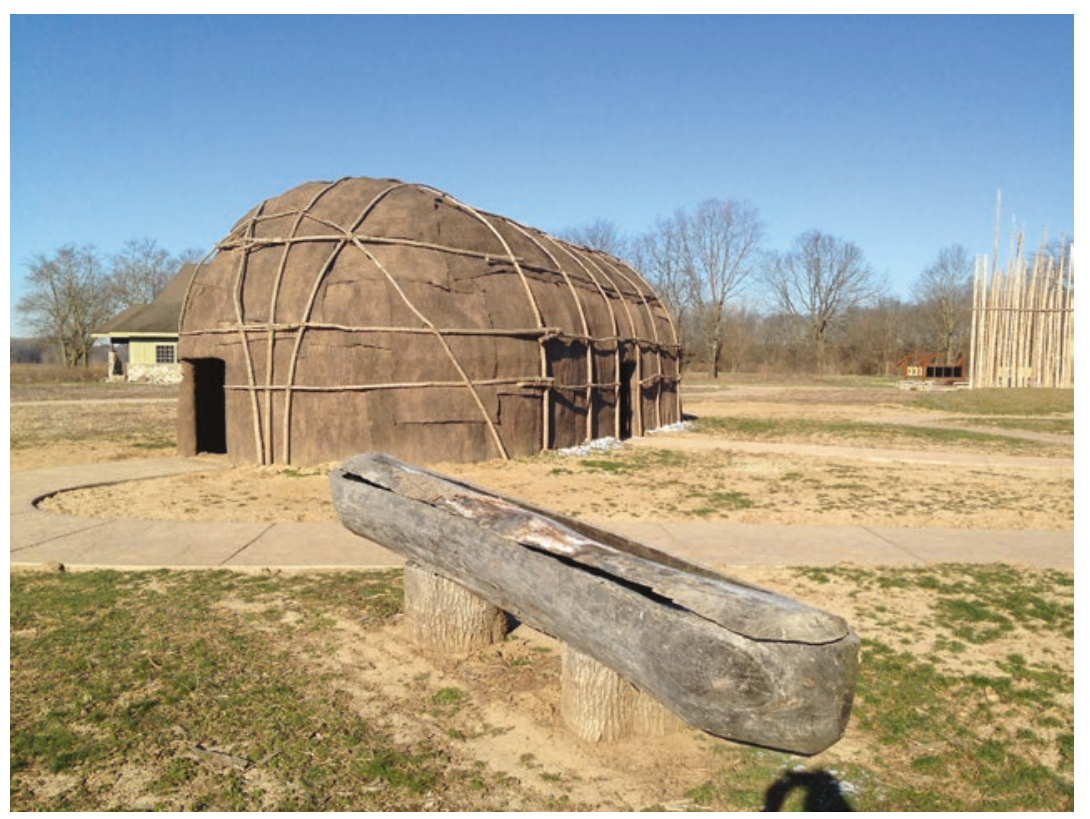

Fig. 12.2 Reconstructed Native American settlement with bent pole and bark-covered structures at Strawtown Koteewi, Hamilton Co., Indiana (Photo: Elizabeth Kryder-Reid)

authority (Adair et al. 2011), participatory heritage (Roued-Cunliffe and Copeland 2017), democratization of heritage (Coghlan 2017), and even decolonization (Atalay 2006; Lonetree 2012), government-controlled sites appear slower to embrace these trends. Some resistance may be attributed to the maze of mandated legal and bureaucratic rules in which government institutions operate, but an even more plausible explanation is that sharing control is predicated on questioning the established authority and fundamental principles of state-derived power, particularly in colonial settings. It strikes at the fundamental nature of the relationship between state authority and citizens, and it exposes contradictions between the espoused principles of a presumed "public heritage" and the realities of proprietary and neoliberal practices of government-owned sites. 


\section{Government, an Ideology of Public Heritage, and Native Americans}

These case studies expose the complexities of assumptions about what "public heritage" means (Holt 2010), and it reveals the ways in which the past as public heritage is simultaneously alienating and democratizing (Zimmerman 2011). Regarding the former, the controversies around the sites are based in fundamental ideologies of settler colonial understandings of cultural heritage and operate in ways that continue to marginalize and exclude Native people. In 2016, the Indiana park system celebrated its centennial. Its founder, Richard Lieber, was concerned that foresting and agriculture were rapidly destroying what he called the state's "original domain"- that is, its pre-European settlement landscape. He wanted to preserve its most pristine areas, which he valued as "not mere picknicking places...." [but] "rich storehouses of memories and reveries. They are guides and counsels to the weary and faltering in spirit. They are bearers of wonderful tales to him who will listen; a solace to the aged and an inspiration to the young" (Smith 1932). In Lieber's view, the parks were unquestioned expressions of manifest destiny tempered with a conservation ethic bespeaking his German origins. The pristine landscape was being preserved for the benefit of the citizens of Indiana. Not only were the origins of the earthworks themselves still being debated, but the Native peoples displaced over the previous century were marginalized from the narratives and from any decision-making process.

The cases of Strawtown Koteewi and Mounds State Park are a microcosm of the intersections of archaeology's origin as scientific colonialism (see Zimmerman 2001: 169; Atalay 2006: 280-284 for discussions) and government endorsement of such archaeological paradigms to frame the rights and responsibilities of controlling cultural resources. Besides taking land and resources as part of economic colonialism, even control of information about colonized peoples shifted to colonizers. Just as they did with land and natural resources, colonizers, acting with and without governmental sanction and support, transformed information about cultural practices, histories, and belief systems into intellectual products they thought more useful or meaningful. In the USA, the idea that the past is public heritage, and therefore part of the role of government to protect and preserve it, also reflects a settler colonial ideology that framed the development of an American identity, and along with it, an American heritage. 
Many scholars and politicians have described America as a land of immigrants, which according to a metaphor in use since the late 1700s, created a cultural "melting pot" that eventually stripped away national identities, languages, and heritages in favor of a more homogeneous identity as American. To a degree this seems self-evident as an historical process, particularly among European immigrants. Others argue that assimilation often was forced and that many groups held onto their original cultural identities as long as possible. They offer that a more appropriate metaphor might be a "salad bowl" in which the core ingredients stay the same even though mixed together, with only a thin overlay of dressing that might be considered uniquely American. Others are nativists who generally are against immigration because it destroys or at least disturbs existing American cultural values. Some of them maintain that later-arriving ethnic groups should have lower political or legal status. Ironically, the Indigenous nations of the continent probably were the original nativists. They often resisted immigration, but by the early 1900s were thought to be conquered and soon to be fully assimilated with their history absorbed as part of American history. Certainly, that proved not to be the case, and many still resist when it comes to a wide range of heritage issues including repatriation and even recognition of sites of conscience, which some might think should be noncontroversial (Zimmerman 2007).

During the Progressive Era of the 1910s-1920s, the Cultural Democracy Movement, promoted by such activists as Horace Kallen (1924: 43) and W.E.B. DuBois (1940), advocated cultural pluralism (the salad bowl approach) as a way to counter the demands of Euromerican nativists for a single or "true" American culture, but also assertions of white supremacy. That struggle echoes into contemporary debates about cultural pluralism, and it created puzzling ideological contradictions about heritage. Pluralism pushed for equality and participation in cultural life and policy, that is, cultural democracy. Adams and Goldbard (1995) note that as a feature of American's thematic universe, cultural democracy, created a dynamic interaction between contending ideologies, struggling against racist articulations of monoculture and liberal ideas of the "melting pot." Cultural democracy was always an insurgent notion, pushing against dominant values. The ideas persist because its core resonates with the lived experiences of people who refuse to be dismissed or "melted down." Cultural democracy was promoted as a way to bring Indigenous people into the modern world without damaging 
their essence. In other words, it wanted to respect Indigenous autonomy, yet it wanted them to be part of the modern world in which everyone could recognize and share elements of identity and heritage. Cultural democracy didn't want to change Indigenous people, but that effectively essentialized them. They became "our Indians" or "America's Indians" in popular media, imagined as primitive and locked in time, and easily understood (compare with Deloria 1969: 12-16).

For many Native Americans, settler value systems associated with democracy, equality, and equal rights sit at the core of public ownership of Native homelands, Native heritage, and access to both, evidence continued colonialization and even seen to contradict the values settlers espouse. Colonization and contradiction symbolize the entire history of Native-settler interactions which has included such settler notions as terra nullius, and Manifest Destiny, which were rationalizes for taking Native lands, and the Mound Builder Myth, which sought to create a deep European history for North America while erasing the primacy of Native Americans on the land. ${ }^{8}$ Native people also saw their history erased by settler scholars who did not understand the nature of Native oral tradition and assumed because there was little evidence of written language to record tribal histories that Native Americans were peoples without a history or at least were prehistoric. Native peoples developed deep and lingering distrust of anthropological and especially archaeological constructions of Native pasts (Deloria 1995). Coupled with desperate struggles for both physical and cultural survival, removal from homelands, confinement onto reservations, and a wide range of federal efforts to force Native assimilation left little power to challenge settler takeover of their heritage. Thus, Native history became American history. Native ancestral places, artifacts, and human remains became public heritage, not the heritage of particular Native nations whose ancestors were traditional owners (Zimmerman 2016). Federal law and policy supported the concept of public heritage. The 1906 Antiquities Act and creation of early National Parks during the Progressive Era included archaeological sites and objects, and eventually national monuments, historic sites, and historic landmarks, many of them centered on Native archaeological sites.

This indicates that settler society maintained a substantial interest in Native Americans, but what they learned was filtered through non-Native scholarship and popular culture such as books and especially film. During this time, Native American-presented traditional history and detail about 
their ancestral cultures was mostly silent for settler cultures. These voices were heard in only limited ways starting in the late 1940s with treatybased land claims, which also proved to be legally problematic. By this time, state park systems had been developed, some of them based on nationally recognized ancestral Indian sites such as Mounds State Park.

By the time of the Civil Rights Movement starting in the early 1960s, there was realization that the American melting pot never really materialized. Ideals about equal rights, largely unmet for minority cultures led to wide-ranging social justice laws. For Indians, this mostly started in the late 1960s with a series of acts with relevance to heritage: Indian Gaming Regulatory Act; American Indian Religious Freedom Act; Arts and Craft Board; National Historic Preservation Act with amendments and regulations providing for Tribal Historic Preservation Officers (THPOs) and recognition and protection for Traditional Culture Properties (TCPs) and then into the early 1990s with the National Museum of the American Indian Act and especially NAGPRA.

What happened was a major shift in which Native Americans became "real" in terms of sovereignty over their heritage, able to tell their own stories about their pasts and able to reclaim ancestral remains, sacred objects, and items of cultural patrimony from any institutions such as museums, universities, and federal agencies. Even though NAGPRA was enacted in 1990, it does not affect private property or entities without federal involvement, nor does it have authority over Native materials held by museums or other organizations outside the USA. Worth noting is that more than thirty states also enacted Native American burial site protection and repatriation, many of them well ahead of NAGPRA.

Mounds State Park was already established and well underway with interpretation and excavation, tourism, and even limited interaction with some of the tribes for ceremonial use of the site. Strawtown Koteewi became a county park almost a decade after NAGPRA, but archaeological excavation of sites in the park and public archaeology programming began with little consultation with tribes possibly affiliated with the sites. Eventual efforts to consult with Indiana tribes, first with the federally unrecognized Miami Tribe of Indiana, which under NAGPRA were not allowed. Eventually, negotiations with the federally recognized Miami of Oklahoma led to issues discussed above. Both parks were by this time well incorporated into the local fabric, incorporating much more than archaeology into park activities and programming, which created varying heritage valuation, and controversy for each park. 


\section{Government, Contested Heritage, and Stakeholders}

An examination of heritage and government must take into account the larger context of developments in advanced industrialized democracies over the past 30 years that have led to both internal and external challenges to the traditional bases of their political power. The result has been a rapidly changing political landscape characterized by "an ideological and cultural shift from collective solutions toward individualism and a Zeitgeist heralding private enterprise and "the market" as the superior resource allocating mechanism" (Pierre 2000: 2). At the same time, there has been a growing trend to recognize the importance of collaboration, transparency, co-production, and accountability in creating effective governance and building public value, including promoting government-to-government and interagency cooperation, public-private partnerships, and greater citizen participation (Arganoff 2012; Box 2007; Moore 1995; O'Flynn et al. 2014). In both government and for-profit sectors, there has also been a move toward privileging stakeholders in decision-making and planning processes (Freeman 1984; Bonnafous-Boucher and Rendtorff 2016). The heritage sector has similarly embraced concepts of stakeholders and public value (Comer 2015; Magliacani 2015; Manes-Rossi et al. 2016; Scott 2016). In Aotearoa New Zealand, for example, 1840 Treaty of Waitangi and the more recent passage of Treaty of Waitangi Acts of 1975 and 1985 as well as the Local Government Act 2002 helped establish a framework for Maori collaboration in decision making and for developing bicultural museum practices (Bell et al. 2017; Legget 2017; Hong 2014).

At both Mounds and Strawtown, the government officials charged with overseeing the sites were required to navigate diverse stakeholders' interests including those of residents, recreational users, heritage professionals, Native American groups with cultural affiliation to the sites, advocacy groups (e.g., Indiana Forest Alliance, Indiana Archaeology Council, Indiana Wildlife Federation) with interests in the sites' natural and cultural resources, local and state elected officials, governmental agencies (e.g., Environmental Protection Agency, National Park Service), the press, and those with economic development interests, to list only a few. Among these competing interests, there was a tension at both sites between economic development and preservation. The Mounds Lake project is particularly stark in this regard. Although the project promoters have couched the reservoir as a safe, dependable water supply for the 
future, the impetus of the project was and remains to stimulate the local economy. Opponents are largely preservation-driven, rallying around saving what would be destroyed by the reservoir, whether that is access to a free-flowing White River, protecting the Star Nosed mole, or concern over erosion of the mounds.

The mission of the Indiana DNR is "to manage and interpret our properties' unique natural, wildlife, and cultural resources using the principles of multiple use and preservation, while sustaining the integrity of these resources for current and future generations." But the DNR officials who have expressed opposition to Mounds Lake project off-therecord, however, must also contend not only with the local government entities that prioritize economic development, but also with a state governor and legislature that are pro-business and supportive of neoliberal notions of the role of government. In 2015, then Indiana Governor Michael Pence issued a statement supporting the reservoir project saying that "The vision for that reservoir serves both the long-term water interests of the state of Indiana, ... (and) the opportunity to develop this region in a fresh way that will attract new investment and attract people to the community" (de la Bastide 2015).

The Strawtown Koteewi case is subtler in the tensions between economic development and preservation, but they are still important factors in the Parks Department's management of the site. A closer look at the Department's mission statement is telling. It identifies residents and tourists as the target audience, and it serves their leisure and recreation needs. Staff members do this by preserving parks and offering natural resource education and services. This mission-driven goal to provide recreation for residents and tourists in turn helps drive the economic development of the county by attracting tax-paying citizens and leisure dollar-spending tourists. It enhances the reputation of the county as a desirable place to live and perhaps even helps lure those interested in more sustainable lifestyles to the less developed fringes of this Indianapolis outer suburb. From this standpoint, it is not surprising that in the face of conflict over the control of Native American cultural heritage the county invests in a mock dig and reconstructed Indian village at Strawtown. The needs and concerns of the both archaeological and Native communities have little to do with the core mission of the Hamilton County Parks and Recreation Department. It is also apparent that the logic of governmental control of these sites is predicated on a capitalist assumption of cultural resources as property. These are 


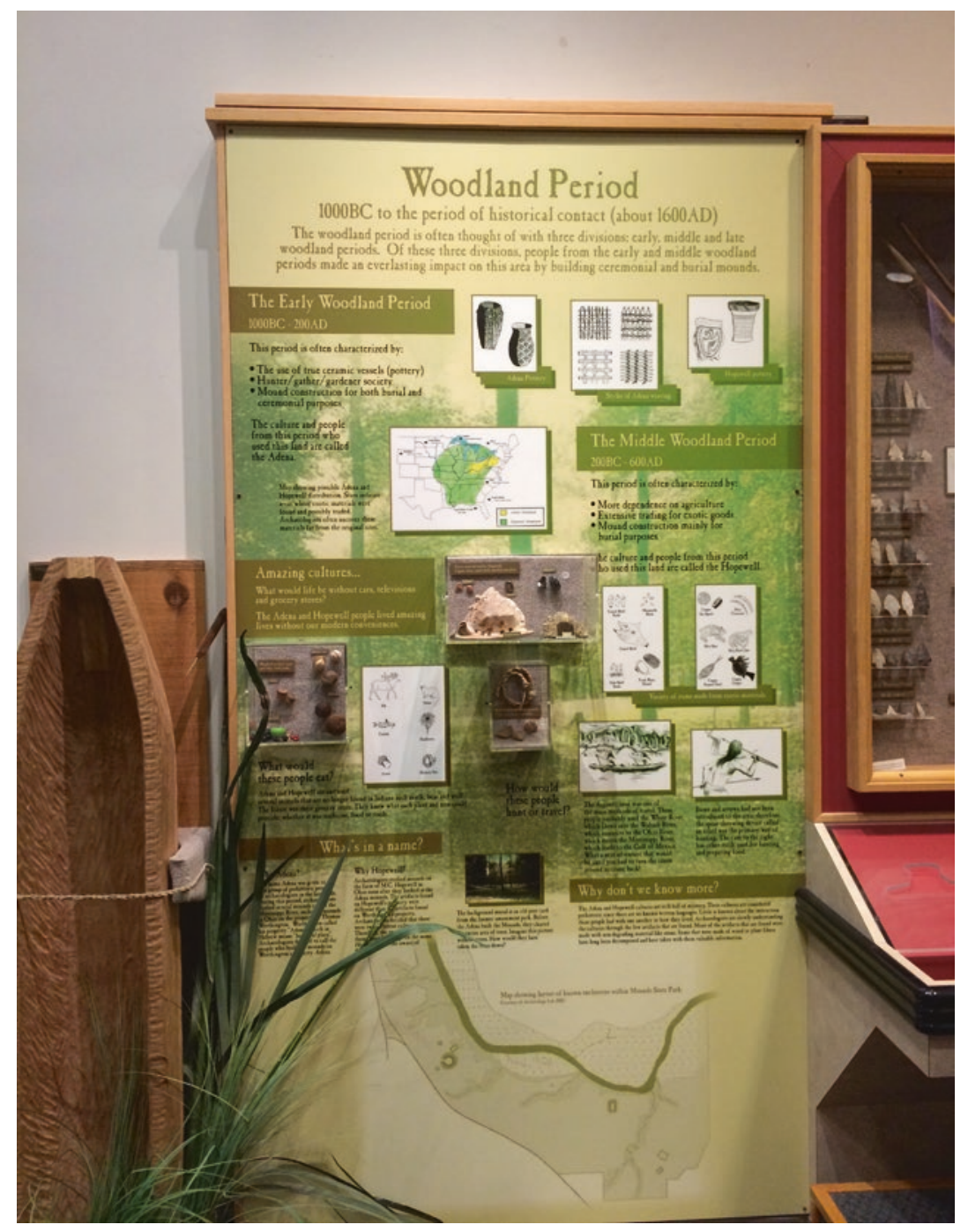

Fig. 12.3 Exhibit at the Mounds State Park Nature Center (Photo: Elizabeth Kryder-Reid) 
community assets to be managed within a broader economic exchange between taxes paid by citizens and the amenities and services provided in return.

The discourse surrounding the cultural contestations at the Indiana sites is eerily similar. While the cultural continuity of the "Moundbuilders" and historic Native Americans has been established, the interpretive narratives at the parks embed the Native history in a frozen past, making little connection between the sites and living tribal communities. Furthermore, the parks gloss over altogether the history of warfare and Indian removal that created the "pristine" areas Lieber sought to protect. For example, at the Mounds State Park interpretive center, the exhibit panels tracing the history of Native Americans on the site present a relatively detailed analysis of the Adena-Hopewell cultures of the Middle Woodland. The next panel, however, in typical settler colonial narrative uses passive voice to describe the dispossession of Native lands. Under the heading "Villages, farms, interurban, amusement: this area is full of history and intrigue," the text reads, "Before the 1800s, the Miami Indians controlled much of the northern half of Indiana. By 1794 the Delaware Indians had permission from the Miami to settle on [the] land...In 1821, the majority of the Delaware left the area after the signing of the St. Mary's treaty which gave the land to the United States." The next headline is "Welcome Bronnenberg Family 1820s (Fig. 12.3).”

Given this explicit interpretation in the Mounds site, it is small wonder that the culturally affiliated Native groups have not been an integral part of the site interpretation and were marginalized in the debates over the proposed dam project.

\section{Heritage and Resistance}

As Laurajane Smith and other critical heritage scholars have noted, a central issue of heritage is control (Smith 2006: 276-298). In the cases of Strawtown Koteewi and Mounds State Park, we see the complexity of the struggles for control and the ways in which heritage resources materialized broader struggles for recognition, access to resources, and other symbolic representations of power. The cases also reveal the ways in which heritage was deployed as a strategic asset that provided moral weight or political cover for what were more important but less defensible concerns. These contestations also highlight the resilience of both 
Native and non-Native citizens to activate heritage as a democratizing force and a form of resistance in the face government authority.

The proposal for the dam project that was promoted by a strong coalition of business and political leaders was opposed by an equally strong coalition of citizens who formed organizations such as the "Heart of the River," turned out in droves for public hearings, and staged protests such as the free-flowing river paddle. They mobilized social media and formed alliances with environmental and preservation organizations. The proposal for Mounds Lake is not dead, but as of January 2018, it has been stalled. Clarke Kahlo, one of the organizers of Heart of the River Coalition, which opposed the dam, explained their strategy, "We used a pretty basic model....You form a group, you name a steering committee, and you start reaching out. It does take a little courage to step forward to critique and then to challenge some of these publicly subsidized projects" (Neal 2015). We (Kryder-Reid and Zimmerman with analysis by Jeremy Foutz) conducted a network analysis of the discourse that reinforced Khalo's characterization of the grassroots opposition and particularly the significance of social media as a powerful communication channel for political action in this battle over local control of natural and cultural resources. A discourse analysis of the texts revealed that most prominent topics were economic development, water, and the role of government (Kryder-Reid 2015). ${ }^{9}$ By contrast, as this mapping of the topic networks illustrates (Fig. 12.4), cultural resources had much less weight in the discourse and fewer connections among the topics.

Despite the relatively low frequency and lack of connection of cultural heritage language in the discourse, it was nonetheless deployed strategically as the authorization of the Mounds State Park on the National Register of Historical Places was based on significance of the mounds and related cultural features. An area of legally protected nature preserve and fen, as well as the presence of an endangered bat species, were similarly invoked in opposition to the dam project. Ultimately, heritage became a tool that people opposing the dam project for a variety of reasons used to get what they wanted.

The word frequency tables, network maps, and word clouds (Fig. 12.5) were evocative visualizations of the discourse around these sites, but an equally significant finding of the study was the relative silence of Native peoples both as speakers in the Mounds Reservoir debate and as visibly affected communities. 


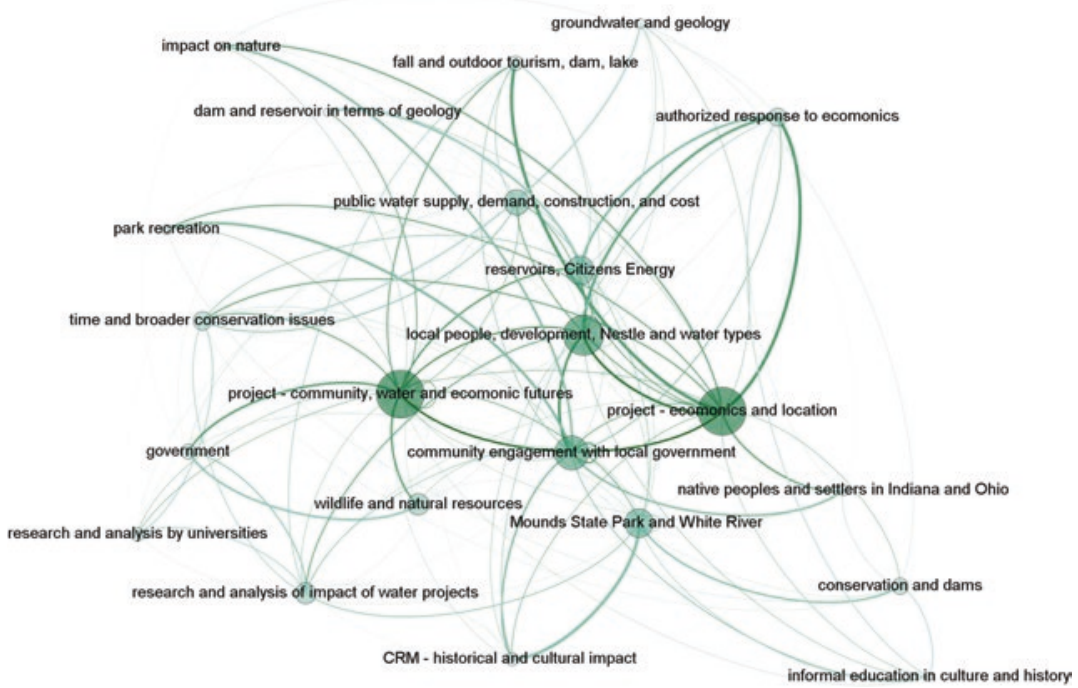

Fig. 12.4 Topic networks map of the Mounds State Park and reservoir discourse analysis (Jeremy W. Foutz, STEAM Workgroup)

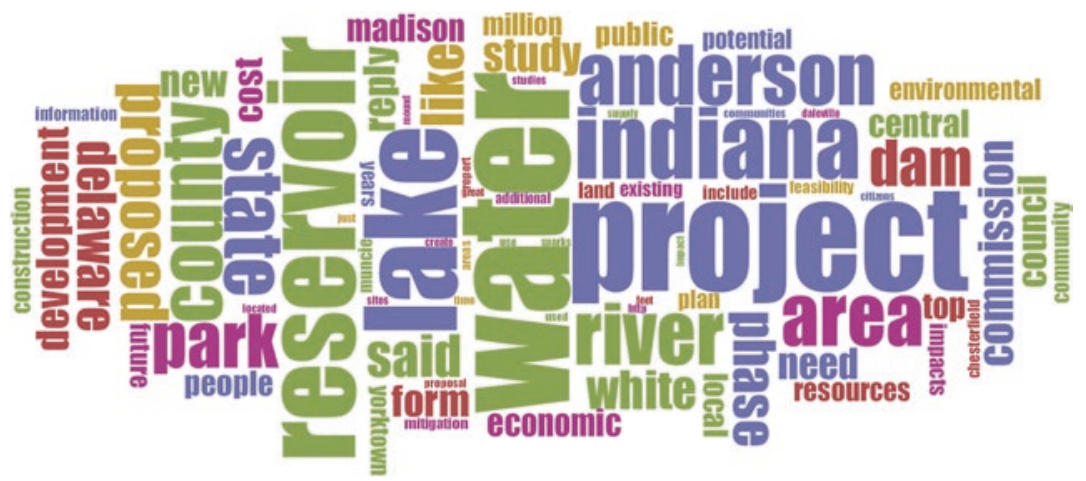

Fig. 12.5 Word cloud of Mounds reservoir project discourse excluding the terms "mound" and "Mounds State Park" (Jeremy W. Foutz, STEAM Workgroup) 
Lack of understanding of the culturally affiliated Indigenous groups is reflected in the Phase 1 feasibility study's recommendation to consult "with the Adena and the Hopewell," terms applied to cultural traditions dating from $1000 \mathrm{BC}$ to $500 \mathrm{AD}$. One of the few sources to call attention to the marginalization of Native people throughout the process was a peer review of the Phase 2 study authored by group of Ball StateUniversity faculty.

The current Phase II study has not engaged with effected [sic] communities, including those with legal, historical or cultural links to the Mounds sites, additional archaeological sites and the White River watershed. Effected [sic] communities potentially include federally recognized tribes in Michigan, Kansas and Oklahoma and individual tribal citizens living within Indiana..., this is not only a matter of how tribes are treated appropriately under NEPA. It is also an environmental justice issue for the region. (Anderson et al. 2015: 3)

While there will inevitably be other contests over control of Mounds State Park and Strawtown Koteewi, the current situation suggests that citizen and Indigenous resistance has influenced the government's management of the sites. The dam project is not proceeding, at this point, and Hamilton County Parks and Recreation agreed to repatriate 90,000 artifacts to the Miami of Oklahoma, an assemblage that goes beyond the legal mandates of the NAGPRA requirements to return objects that are sacred, of cultural patrimony, or related to funerary contexts and instead honors the spirit of the agreement to return objects because they are significant to the Miami people.

\section{CONCLUSION}

The staff of Mounds and Strawtown Koteewi are dedicated heritage professionals who have committed themselves to preserving and interpreting the sites. The Hamilton County Parks and Recreation and Indiana Department of Natural Resources leadership have similarly invested in providing a wide range of opportunities that improve the quality of life of their citizens through access to the sites. The debate around these sites highlights how governmental entities, including tribal, county, and state governments, navigate the often-conflicting agendas and interests of these groups. The debate also exposes the fundamental ideologies 
that frame a "public heritage" within an unspoken settler colonial narrative and that appear to accede to economic interests consistent with neoliberal trends in government. As well, the case highlights the complex dynamics of resistance to governmental actions as grassroots opponents and tribal representatives mobilized cultural heritage through legal and rhetorical strategies to achieve their aims. These two state and local governmental entities are, like most in the US government-run heritage sector, a long way from the public accountability being implemented in cultural institutions in New Zealand and other parts of the world. But the messy and contentious battles over the value and control of heritage in each case also demonstrate the resilient power of citizens to influence decisions when they feel the government is not acting of, by, or, for the people.

\section{Notes}

1. This project was supported by Indiana University's New Frontiers in the Arts \& Humanities Program, a program of the Office of the Vice President for Research funded by the Office of the President. Elizabeth KryderReid is the PI. Co-PIs Elizabeth Wood and Jeremy W. Foutz, principal at STEAM Workgroup, helped to develop the research methodology. Wood facilitated the focus group sessions. Collaborator Larry Zimmerman served as consultant for work with Native American communities. Foutz designed and administered the survey and conducted the statistical analysis of these data. Emma Marston was a graduate research assistant for the first six months of the project. A preliminary version of this analysis was presented by Elizabeth Kryder-Reid at the ACHS Conference in Montreal in June, 2016, in the session "Cultural Contestation: Politics and Governance of Heritage." Zimmerman and Kryder-Reid collaborated on writing this article. We greatly appreciate the assistance of the staff at MSP and SKP, particularly Ted Tapp and Christy Brocken, for generously sharing documents, hosting the focus groups, helping disseminate information and recruit participants, and for their willingness to investigate stakeholderdefined values of the sites they administer.

2. Throughout this chapter, the authors sometimes refer to the parks by common local reference, that is, Mounds State Park will sometimes be shortened to 'Mounds' and Strawtown-Koteewi to 'Strawtown'. Similarly, full site names will be used where a more formal designation is useful.

3. Hamilton County had a population of 274,569 according to the 2010 census and is the fastest growing of Indiana's 92 counties. 
4. The terms Adena-Hopewell, Archaic, Late Woodland, Oliver Phase, and the like are archaeological taxonomic labels, not tribal names. Clear links between tribes at the time of European contact and archaeological taxa used in the Eastern USA do not extend earlier than about $800 \mathrm{AD}$; although tribes certainly moved around before contact, there is no reason to believe that ancestors of the tribes living in the region at the time of contact had not lived in their homelands for millennia as their oral traditions state. See Zimmerman and Makes Strong Move (2008) for a discussion.

5. Funding for the projects included a National Park Service grant for tenth anniversary excavations at Strawtown (over 4300 visitors) and a three-year National Science funded "Research Experience for Undergraduates (REU)" with Indiana University-Purdue University Ft. Wayne (IPFW).

6. As an indication of the complex cultural affiliations with Indiana, under NAGPRA regulations, the Hamilton County Department of Parks and Recreation is responsible for notifying the Absentee-Shawnee Tribe of Indians of Oklahoma; Delaware Nation, Oklahoma; Eastern Shawnee Tribe of Oklahoma; Miami Tribe of Oklahoma; Pokagon Band of Potawatomi Indians, Michigan and Indiana; and the Shawnee Tribe regarding published notices.

7. See Sikich (2017) for a summary story. The online version has internal links to earlier stories, photographs, and video about the issue. Online commenters claimed bias and challenged aspects of reporting in the earlier stories.

8. Discussion of this complex history is well beyond the scope of this paper. See Silverberg (1968), Thomas (2000), and Kehoe (1998: 64-81) for more detail, especially the early development of American anthropology as the primary heritage discipline that documents pre-contact Native American history and culture. For the development of federal law in relationship to Native Americans, see Wilkins and Lomawaima (2001).

9. We collected texts from various sources to define a corpus for our analysis. We then used a Java-based computer program called MALLET (MAchine Learning for LanguagE Toolkit) to determine the discourse topics present in the corpus. Beginning from the assumption of a random distribution of word, the software looks at the frequency, position, and connections to discover which words are used in connection with each other. With each program iteration - standard practice is 500-the program refines a list of associated words around central topics. 


\section{REFERENCES}

Adair, B., Filene, B., \& Koloski, L. (2011). Letting Go? Sharing Historical Authority in a User-Generated World. Philadelphia: Pew Center for Arts \& Heritage.

Adams, D., \& Goldbard, A. (1995). Cultural Democracy: An Introduction to an Idea. http://www.wwcd.org/cd2.html. Accessed 30 June 2012.

Agranoff, R. (2012). Collaborating to Manage: A Primer for the Public Sector. Washington, DC: Georgetown University Press.

Anderson, B., et al. (2015, March 4). Executive Summary, Memorandum for Record Subject: Mounds Lake Reservoir Phase II Study Preliminary Peer Review. Muncie, IN: Ball State University.

Atalay, S. (2006). Indigenous Archaeology as a Decolonizing Practice. American Indian Quarterly, 30(3), 280-310.

Bell, R., et al. (Eds.). (2017). The Treaty on the Ground: Where We Are Headed and Why It Matters. Auckland: Massey University Press.

Bonnafous-Boucher, M., \& Dahl Rendtorff, J. (2016). Stakeholder Theory: A Model for Strategic Management. Cham: Springer.

Box, R. C. (Ed.). (2007). Democracy and Public Administration. Armonk, NY: M.E. Sharpe.

Cochran, D. R., \& McCord. B. K. (2001). The Archaeology of Anderson Mounds, Mounds State Park, Anderson, Indiana. Reports of Investigation 61. Muncie, IN: Archaeological Resources Management Services, Ball State University.

Coghlan, R. (2017, June 16). 'My Voice Counts Because I'm Handsome.' Democratising the Museum: The Power of Museum Participation. International Journal of Heritage Studies. https://doi.org/10.1080/135272 58.2017 .1320772 .

Comer, D. C. (2015). Archaeology as a Global Public Good and Local Identity Good. In P. F. Biehl, D. C. Comer, C. Prescott, \& H. A. Soderland (Eds.), Identity and Heritage: Contemporary Challenges in a Globalized World (pp. 11-26). Cham: Springer.

de la Bastide, K. (2015, June 10). Pence: Reservoir Proposal Has Merit: Anderson Council to Consider Joining Commission. The Herald Bulletin. http://www.heraldbulletin.com/news/local_news/pence-reservoir-proposal-has-merit/article_77ec4aca-0f9a-1le5-a0cl-ef404f8243b7.html. Accessed 30 May 2016.

Deloria, V., Jr. (1969). Custer Died for Your Sins: An Indian Manifesto. New York: Avon.

Deloria, V., Jr. (1995). Red Earth, White Lies: Native Americans and the Myth of Scientific Fact. New York: Scribner.

DuBois, W. E. B. (1940). Dusk of Dawn: An Essay Toward and Autobiography of a Race Concept. New York: Harcourt, Brace \& Co. 
Freeman, E. R. (1984). Strategic Management. Marshfield, MA: Pitman Publishing. Hamilton County Website. n.d. Koteewi Trace. http://www.visithamiltoncounty. com/listings/Koteewi-Trace/1854/0/. Accessed 30 May 2016.

Harrison, R. (2012). Heritage: Critical Approaches. New York: Routledge.

Holt, S. A. (2010). The Past as a Place: Challenging Private Ownership of History in the United States. In L. Jensen, J. Leerseen, \& M. Mathijsen (Eds.), Free Access to the Past: Romanticism, Cultural Heritage and the Nation (pp. 279-289). Leiden: Brill.

Hong, B. (2014). National Cultural Indicators in New Zealand. Cultural Trends, 23(2), 93-108.

Kallen, H. (1924). Culture and Democracy in the United States. New York: Boni \& Liveright.

Kehoe, A. B. (1998). The Land of Prehistory: A Critical History of American Archaeology. New York: Routledge.

Kryder-Reid, E. (2015, November). Caring About and Caring for Heritage Landscapes: Two Contested Sites in Indiana. Paper presented at the American Anthropological Association Annual Meeting, Denver, CO.

Kryder-Reid, E., Foutz, J. W., Wood, E., \& Zimmerman, L. J. (2017, June 22). 'I Just Don't Ever Use That Word': Investigating Stakeholders' Understanding of Heritage. International Journal of Heritage Studies. https://doi.org/10.1080/13527258.2017.1339110.

Laurence, A. (2010). Heritage as a Tool of Government. In R. Harrison (Ed.), Understanding the Politics of Heritage (pp. 81-114). Manchester: Manchester University Press.

Legget, J. (2017). Shared Heritage, Shared Authority, Shared Accountability? Co-creating Museum Performance Criteria as a Means of Embedding 'Shared Authority'. International Journal of Heritage Studies. Published online [date TBA].

Lonetree, A. (2012). Decolonizing Museums: Representing Native America in National and Tribal Museums. Durham: University of North Carolina.

Magliacani, M. (2015). Managing Cultural Heritage: Ecomuseum, Community, Governance and Social Accountability. New York: Palgrave Macmillan.

Manes-Rossi, F., Allini, A., Spanò, R., \& Dainelli, F. (2016). Changing Performance Measurement Towards Enhanced Accountability: Insights from the British Museum. International Journal of Public Sector Performance Management, 2(4), 331-347.

McCullough, R. G. (Ed.). (2011). Tenth Anniversary of Archaeology in a Public Venue at Strawtown Koteewi Park, Hamilton County, Indiana: 2010 Archaeological Investigations at the Strawtown Enclosure (12H883) and 12H1052. Reports of Investigations 1101. Washington, DC: U.S. Department of the Interior, Historic Preservation Fund. 
Moore, M. H. (1995). Creating Public Value: Strategic Management in Government. Cambridge: Harvard University Press.

Mounds State Park, Interpretive Master Plan. (2011). http://in.gov/dnr/parklake/files/sp-Mounds_State_Park_IMP_2011.pdf. Accessed 17 May 2016.

Neal, A. (2015, October 12). From the South Wall: Watchdogs Win. Indiana Policy Review. http://inpolicy.org/2015/10/andrea-neal-watchdogs-winagainst-favored-projects/. Accessed 30 May 2016.

O'Flynn, J., Blackman, D., \& Halligan, J. (Eds.). (2014). Crossing Boundaries in Public Management and Policy: The International Experience. London: Routledge.

Pierre, J. (2000). Introduction: Understanding Governance. In J. Pierre (Ed.), Debating Governance: Authority, Steering and Democracy (pp. 1-12). Oxford: Oxford University Press.

Roued-Cunliffe, H., \& Copeland, A. (Eds.). (2017). Participatory Heritage. London: Facet Publishing.

Scott, C. A. (Ed.). (2016). Museums and Public Value: Creating Sustainable Futures. New York: Routledge.

Sikich, C. (2017, June 17). Hamilton County to Return Artifacts Excavated from Strawtown Park to Miami Tribe. Indianapolis Star. https://www.indystar.com/story/news/local/hamilton-county/2017/06/07/hamilton-county-return-artifacts-excavated-strawtown-park-miami-tribe/373209001/. Accessed 11 Jan 2018.

Silverberg, R. (1968). Mound Builders of Ancient America: The Archaeology of a Myth. Greenwich, CT: New York Graphics Society.

Smith, D. (1932). The Mound Builders of Indiana and the Mounds State Park in Madison County Near Anderson, Indiana. Indianapolis: Department of Conservation, State of Indiana, Division of Lands, and Waters.

Smith, L. (2006). The Uses of Heritage. London: Routledge.

Smith, L., \& Waterton, E. (2009). Heritage, Communities, and Archaeology. London: Duckworth.

Squire, E. G., \& Hamilton Davis, E. (1848). Ancient Monuments of the Mississippi Valley. New York: Bartlett \& Welford.

Thomas, D. H. (2000). Skull Wars: Kennewick Man, Archaeology, and the Battle for Native American Identity. New York: Basic Books.

Wilkins, D. E., \& Lomawaima, K. T. (2001). Uneven Ground: American Indian Sovereignty and Federal Law. Norman: University of Oklahoma Press.

Zimmerman, L. J. (2001). Usurping Native American Voice. In T. Bray (Ed.), The Future of the Past: Archaeologists, Native Americans, and Repatriation (pp. 169-184). New York: Garland Publishing.

Zimmerman, L. J. (2007). Plains Indians and Resistance to 'Public' Heritage Commemoration of Their Pasts. In H. Silverman \& D. F. Ruggles (Eds.), Cultural Heritage and Human Rights (pp. 144-158). New York: Springer. 
Zimmerman, L. J. (2010). Archaeology Through the Lens of the Local. In A. Stroulia \& S. B. Sutton (Eds.), Archaeology in Situ: Local Perspectives on Archaeology, Archaeologists, and Sites in Greece (pp. 473-480). Lanham, MD: Lexington Books.

Zimmerman, L. J. (2011). Is the 'The Past is a Public Heritage' Democratizing or Alienating? Paper presented at the American Anthropological Association Annual Meeting, Montreal. http://www.academia.edu/16637059/Is_The_ Past_is_a_Public_Heritage_Democratizing_or_Alienating. Accessed 11 Jan 2018.

Zimmerman, L. J. (2016). Repatriating Buhl Woman, Keeping Our Word, and Making NAGPRA Work. In M. J. Trubitt (Ed.), Research, Preservation, Communication: Honoring Thomas J. Green on his Retirement from the Arkansas Archeological Survey. Research Series, 14. (pp. 9-17). Fayeteville: Arkansas Archaeological Survey.

Zimmerman, L. J., \& Dawn Makes Strong Move. (2008). Archaeological Taxonomy, Native Americans, and Scientific Landscapes of Clearance: A Case Study from Northeastern Iowa. In A. Gazin-Schwartz \& A. P. Smith (Eds.), Landscapes of Clearance (pp. 190-211). Walnut Creek, CA: Left Coast Press. 